\title{
К ВОПРОСУ ОБ ОСНОВАНИЯХ ИЗЬЯТИЯ ЗЕМЕЛЬ ДЛЯ ГОСУДАРСТВЕННЫХ И МУНИЦИПАЛЬНЫХ НУЖД
}

\section{ON THE ISSUE OF GROUNDS FOR LAND WITHDRAWAL FOR STATE AND MUNICIPAL NEEDS}

\section{A. Gudkov \\ A. Krasilschikov V. Mishchenko}

Summary: This article discusses both the grounds and problematic issues of land acquisition. According to the authors, the innovations introduced by the Federal Law N 499-FZ did not solve the problematic issues. In this regard, it is proposed to legislate the definition of state (municipal) needs, with the obligatory disclosure of the characteristics that determine them. The authors note that in some cases, citizens do not receive adequate compensation for the seizure of the land in their possession. State protection of public interests in the form of seizure of land for construction is an exceptional measure. The authors emphasize that the proper registration of rights to a land plot will allow the right to compensation in case of seizure to be realized. The seizure procedure must comply with the RF LC, the decision on the seizure of the site must be made by a certain body within the framework of its powers.

Keywords: land plot, public interests, needs, citizens, property, redemption, withdrawal, use, possession.

\author{
Гудков Анатолий Иванович \\ К.ю.н., дочент, ВЮИ ФСИН России, \\ gudkovaniv@yandex.ru \\ Красильщиков Анатолий Владимирович \\ К.ю.н., дочент, ВЮИ ФСИН России \\ krasilschikov@inbox.ru \\ Мищенко Вячеслав Иванович \\ К.фр.н., дочент, ВЮИ ФСИН России, \\ vyacheslav-mischenko@mail.ru
}

Аннотация: В настоящей статье рассмотрены как основания, так и проблемные вопросы изъятия земель. По мнению авторов, нововведения, внесенные Федеральным законом N 499-Ф3, не решили проблемных вопросов. B связи с этим предложено законодательно закрепить определение государственных (муниципальных) нужд, с обязательным раскрытием признаков, их определяющих. Авторы отмечают, что в некоторых случаях граждане не получают адекватную компенсацию за изъятие находящегося в их владении земельного участка. Защита государством публичных интересов в виде изъятия участка под строительство является исключительной мерой. Авторы подчеркивают, что надлежащее оформление прав на земельный участок позволит реализовать право на возмещение при изъятии. Процедура изъятия должна соответствовать ЗК РФ, решение об изъятии участка должно быть принято определенным органом в рамках своих полномочий.

Ключевые слова: земельный участок, публичные интересы, нужды, граждане, собственность, выкуп, изъятие, пользование, владение.

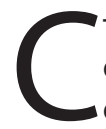
табильность отношений собственности можно обеспечить в полной мере, только если четко определены основания и порядок прекращения права собственности. Гарантируя равенство всех форм собственности, Конституция РФ [1] устанавливает принцип равной защиты всех субъектов правоотношений собственности.

Определяя и защищая публичные интересы как общезначимые потребности, которые нужны обществу для обеспечения его жизнедеятельности, можно говорить о важности поступательного развития системы правового регулирования земельных отношений института прекращения прав на земельные участки в порядке их изъятия для государственных или муниципальных нужд (далее - изъятие). В земельном законодательстве РФ отсутствует понятие публичных интересов, тем не менее, они многогранны. В связи с этим мы полагаем, что значимость роли публичных интересов для института изъятия земельных участков для государственных или муниципальных нужд, бесспорно, велика, поскольку они выступают одновременно как внеправовое обоснование справедливости введения посягающих на частные интересы правообладателей ограничений и как социально-экономический ориентир, который определяет содержание и логику правового регулирования в рассматриваемой области.

Земельный участок является самостоятельным объектом недвижимости. Основания изъятия нашли свое закрепление в ст. 49 Земельного кодекса РФ [2] (далее ЗК РФ). Это выполнение международных договоров России, строительство, а также перечень иных оснований, которые определены в федеральных законах. Глава VII.1 ЗК РФ устанавливает сам порядок изъятия. Предшествует этому соответствующее решение уполномоченных органов (ст. 56.2 3К РФ). Вместе с тем, считаем целесообразным рассмотреть отдельные проблемные вопросы затронутой нами темы. Это является актуальным направлением для исследования, так как в данной области имеется большое количество пробелов. Так, в частности, федеральным законом от 31.12.2014 г. N 499-Ф3 [4] 3К РФ был дополнен главой VII.1 «Порядок изъятия земельных участков для государственных или муниципальных нужд». Нововведениями закреплялись: условия изъятия земельных участков, определялись уполномоченные 
органы, к полномочиям которых было отнесено принятие решения об изъятии, установлен порядок принятия такого решения.

Подобное изъятие, фактически, ограничивает «безусловность» права частной собственности, поскольку осуществляется, зачастую, принудительно, без согласия владельца. При этом наличие такого признака, как «государственные и муниципальные нужды» является едва ли не самым важным условием изъятия участка из частной собственности.

Кроме того, отдельные статьи были посвящены особенностям заключения соглашения об изъятии, определению размера и выплате возмещения. Однако, следует отметить, что даже с учетом внесенных изменений недостатки правового регулирования механизма изъятия не были устранены. Так, в соответствии со ст. 49 ЗК РФ, изъятие для достижения указанных целей возможно только в исключительных случаях. К таким исключениям относится потребность государства в расположении на конкретных земельных участках значимых объектов в целях решения государственных или муниципальных задач при условии отсутствия альтернативных вариантов расположения таких объектов. Исходя из этого, на практике сразу возникает проблема: каким образом полномочные органы будут доказывать наличие государственных или муниципальных нужд применительно к конкретному земельному участку, какие доводы ими будут приведены в части того, что именно данный земельный участок необходим, и почему невозможна реализация данных нужд иными способами.

Существование указанной проблемы является следствием отсутствия законодательно установленного определения государственных или муниципальных нужд. Вследствие чего в суды поступает множество заявлений об оспаривании решений об изъятии земельных участков в связи с отсутствием на то законных оснований. Так, в 2018 г. в Арбитражный суд Ростовской области обратилось акционерное общество с требованием о признании незаконным распоряжения Правительства Ростовской области «Об изъятии земельного участка для государственных нужд» [7. С. 88]. Изъятие земель предполагалось для проведения сельскохозяйственных работ на данном участке. Суд решил исковые требования акционерного общества удовлетворить на основании того, что необходимость изъятия не свидетельствовала об удовлетворении публичных нужд в интересах общества. В судебной практике встречаются также абсолютно противоположные решения, что ясно прослеживается из Определения Конституционного Суда РФ от 30.09.2019 г. N 2438-O [5]. Для решения вышеуказанной проблемы предлагаем законодательное закрепление рассматриваемого определения с обязательным раскрытием признаков, определяющих государственные или муниципальные нужды.

Кроме того, полагаем целесообразным указать на серьезную проблему правового регулирования, связанную с выплатой возмещения при изъятии земельных участков. Принцип предварительного и равноценного возмещения является основополагающим и закреплен в п. 3 ст. 35 Конституции РФ.

В ЗК РФ и ГК РФ предусмотрен добровольный и принудительный порядок изъятия. При добровольном изъятии с каждым правообладателем земельного участка и расположенного на нем недвижимого имущества, в соответствии со ст. 56.9 ЗК РФ, заключается соглашение об изъятии, в котором в обязательном порядке указываются размер и порядок выплаты возмещения, определяемого по результатам проведенной оценки. В сумму выкупа должны включаться также упущенная выгода и убытки в виде расходов собственников на переезд и обустройство в другом месте.

В случае отказа правообладателя от заключения соглашения об изъятии происходит изъятие земельного участка в принудительном порядке, по решению суда. В этой связи А.Н. Стребкова указывает на такую проблему, как снижение безопасности владения, а также возможность коррупционных действий и злоупотребления властью со стороны уполномоченных органов, которые имеют возможность в принудительном порядке изъять земельный участок. При этом в некоторых случаях граждане не получают адекватную компенсацию за изъятие находящегося в их владении земельного участка в силу отсутствия прозрачности процесса [7. С. 89]. Об этой же проблеме говорит С.М. Саргсян, выявляя случаи недостаточной (несправедливой) компенсации, выплачиваемой правообладателю. В частности, он указывает на то, что в современной системе законодательства РФ отсутствуют точно установленные методические указания определения размера возмещения за изъятие земельных участков. Такое явление влечет за собой выплату несправедливого возмещения правообладателям изымаемых земельных участков [8. С. 26].

Далее, руководствуясь ст. 280 ГК РФ [3] считаем возможным говорить о том, что выкупная цена за изымаемый земельный участок должна определяться на момент, когда уполномоченный орган принял решение изъять земельный участок и сведения об этом внесены в ЕГРН. Однако, ст. 57 ЗК РФ предусматривает, что размер возмещаемых убытков должен определяться, учитывая стоимость изымаемого имущества на день, который предшествует принятию решения об изъятии. Учитывая изложенное, следует указать на наличие противоречия положений гражданского и земельного законодательства в части установления момента, когда выкупная цена земельного участка должна быть опре- 
делена. В данной ситуации мы согласны с позицией Д. Городяниной, которая полагает, что данный проблемный вопрос следует разрешить путем закрепления нормы о том, что выкупная цена определяется на момент уведомления правообладателя земельного участка о произведенной регистрации решения об изъятии земельного участка [6. С. 169].

Как нами уже указывалось, основания для изъятия и сама процедура изъятия установлены ЗК РФ, в том числе, например, таким основанием является строительство автомобильной дороги. Обращаясь к рассмотрению правоприменительной практики, отметим, что при соблюдении властным органом процедуры изъятия, судебная практика достаточно однообразна и неутешительна для собственников. В целях защиты своей собственности владельцы приводят различные доводы, однако не все из них, в сущности, влияют на изъятие и дают реальную возможность сохранить права на участок. Так, Ленинский районный суд г. Курска рассмотрел дело N 2A-2151/2019, в котором истцы оспаривали решение об изъятии. Суд указал, что не уведомление собственников об изъятии земельного участка, не направление проекта соглашения, на которые ссылаются административные истцы, не могут свидетельствовать о незаконности оспариваемого постановления, а указанные обстоятельства могут быть оценены только как нарушение процедуры изъятия земельного участка. Основой для изъятия участка под строительство дороги служит приказ или постановление, утверждающее проект планировки территории, определяющее судьбу спорного участка, и которое также можно попытаться оспорить в суде. Так, Нижегородский областной суд рассмотрел иск владельца земельного участка, который оспаривал подобное распоряжение. В решении по делу N 3A-513/2019 суд указал: с учетом норм градостроительного законодательства РФ отнесение части земельного участка истца к планируемым границам объекта свидетельствует о необходимости решения вопроса об изъятии, между тем проект планировки не содержит таких сведений.

Законодательство, конечно же, предусматривает механизм компенсации ущемленных прав владельца земельного участка. Так, Чкаловский районный суд г. Екатеринбурга, рассматривая дело N 2-1209/2019 об изъятии, указал, что отчет о стоимости, предоставленный истцом, не учитывает часть объектов, находящихся на участке (скважина, колодец, овощная яма, бак металлический и насаждения), и в нем отсутствует обоснование выводов оценщика по расчету убытков Ответчика. При этом в расчете Ответчика суд не согласился с суммой упущенной выгоды, рассчитанной исходя из валового годового дохода от насаждений, поскольку отсутствовали доказательства, позволяющие сделать подобный вывод.

В свою очередь, Карабудахкентский районный суд Республики Дагестан рассмотрел дело N 2- 118/2017 и отказал собственнику в выкупе всего участка на основании проведенной заявителем экспертизы. Отчет, представленный собственником в отношении изымаемого объекта - части участка (38 кв. м), был составлен с нарушением стандартов оценки. При этом экспертом сделан необоснованный вывод о невозможности использования оставшейся части участка размером 1462 кв. м, на котором находятся все объекты собственника, не подпадающие под полосу постоянного отвода.

По результатам исследования заявленной тематики, в завершение сделаем выводы.

1. Несмотря на нововведения, внесенные Федеральным законом N 499-Ф3, ряд проблемных вопросов остался все также не решенным.

2. Защита государством публичных интересов в виде изъятия участка под строительство дороги является исключительной мерой. Надлежащее оформление прав на земельный участок позволит реализовать право на возмещение при изъятии. Процедура изъятия должна соответствовать ЗК РФ, решение об изъятии участка должно быть принято определенным органом в рамках своих полномочий.

3. Изъятие земельного участка не предусматривает предоставление взамен другого участка, а предусматривает лишь денежное возмещение, при этом право собственности прекращается только после выплаты собственнику всех денежных средств.

\section{ЛИТЕРАТУРА}

1. Конституция РФ (с изменениями, одобренными в ходе общероссийского голосования 01.07.2020) // СПС «Консультант Плюс».

2. Земельный кодекс РФ от 25.10.2001 N 136-Ф3 (ред. от 31.07.2020) (с изм. и доп., вступ. В силу с 28.08.2020) // СЗ РФ. 2001. N 44. С. 4147.

3. Гражданский кодекс РФ (часть первая) от 30.11.1994 N 51-Ф3 (ред. от 31.07.2020) // СЗ РФ. 1994. N 32. С. 3301.

4. Федеральный закон от 31.12.2014 N 499-Ф3 (ред. от 29.07.2017) «0 внесении изменений в Земельный кодекс РФ и отдельные законодательные акты РФ» (с изм. и доп., вступ. в силу с 01.01.2019) // СЗ РФ. 2015. N 1 (часть І). Ст. 52.

5. Определение Конституционного Суда РФ от 30 сентября 2019 г. N 2438-0 // СПС «Консультант Плюс».

6. Городянина Д. Споры в Связи с изъятием земельных участков для государственных и муниципальных нужд //Молодой ученый. 2019. N 10. С. 169. 
7. Стребкова А.Н. Изъятие земель // Научные исследования. 2019. N 1 (27). С. 89.

8. Саргсян С.М. Проблемы изъятия земельных участков для государственных и муниципальных нужд // Науки о Земле: вчера, сегодня, завтра: материалы Междунар. науч. конф. (г. Казань, май 2016 г.). Казань: Бук, 2016. С. 26.

○ Гудков Анатолий Иванович (udkovaniv@yandex.ru), Красильщиков Анатолий Владимирович (krasilschikov@inbox.ru), Мищенко Вячеслав Иванович (vyacheslav-mischenko@mail.ru).

Журнал «Современная наука: актуальные проблемы теории и практики»

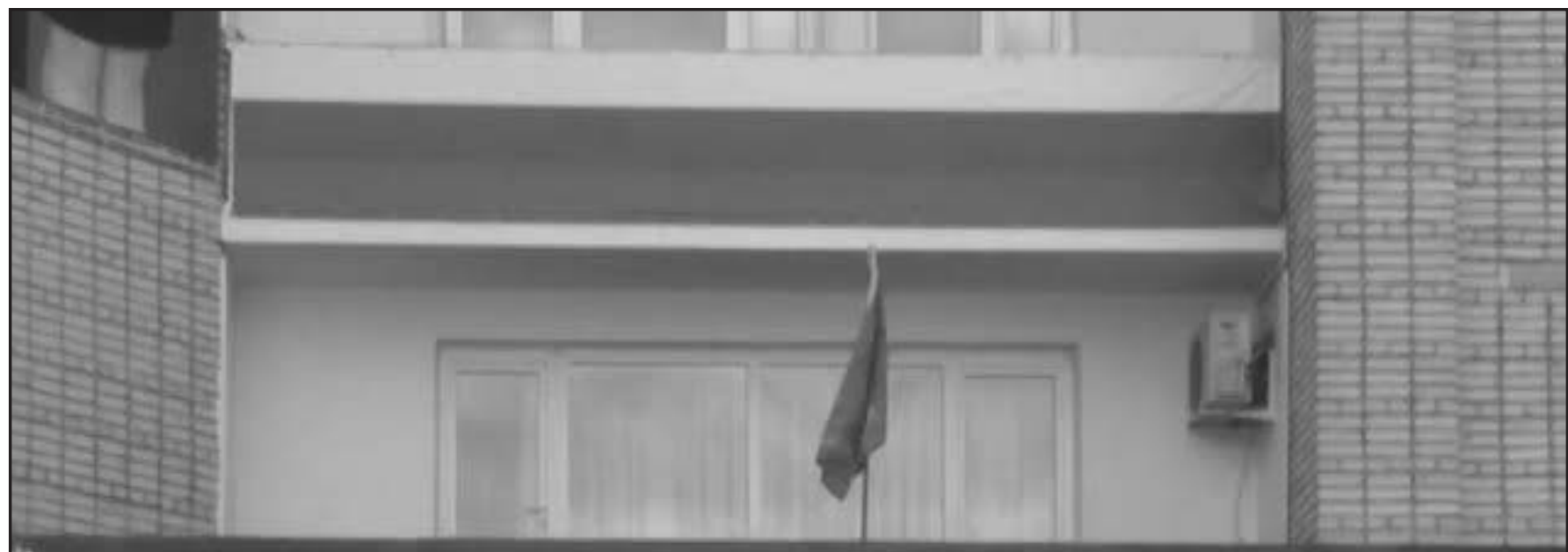
ВЛАДИМИРСКИЙ ЮРИДИЧЕСКИЙ ИНСТИТ 